\title{
Polyketide synthases of Diaporthe helianthi and involvement of DhPKS1 in virulence on sunflower
}

\author{
Michelina Ruocco ${ }^{1 *} \mathbb{D}$, Riccardo Baroncelli ${ }^{2}$, Santa Olga Cacciola ${ }^{3}$, Catello Pane ${ }^{4}$, Maurilia Maria Monti ${ }^{1}$, \\ Giuseppe Firrao ${ }^{5}$, Mariarosaria Vergara ${ }^{6,7}$, Gaetano Magnano di San Lio $^{8}$, Giovanni Vannacci ${ }^{7}$ and \\ Felice Scala ${ }^{1,2,3,4,5,6,7,8,9}$
}

\begin{abstract}
Background: The early phases of Diaporthe helianthi pathogenesis on sunflower are characterized by the production of phytotoxins that may play a role in host colonisation. In previous studies, phytotoxins of a polyketidic nature were isolated and purified from culture filtrates of virulent strains of $D$. helianthi isolated from sunflower. A highly aggressive isolate (7/96) from France contained a gene fragment of a putative nonaketide synthase (lovB) which was conserved in a virulent $D$. helianthi population.

Results: In order to investigate the role of polyketide synthases in $D$. helianthi $7 / 96$, a draft genome of this isolate was examined. We were able to find and phylogenetically analyse 40 genes putatively coding for polyketide synthases (PKSs). Analysis of their domains revealed that most PKS genes of D. helianthi are reducing PKSs, whereas only eight lacked reducing domains. Most of the identified PKSs have orthologs shown to be virulence factors or genetic determinants for toxin production in other pathogenic fungi. One of the genes (DhPKS1) corresponded to the previously cloned $D$. helianthi lovB gene fragment and clustered with a nonribosomal peptide synthetase (NRPS) -PKS hybrid/lovastatin nonaketide like A. nidulans LovB. We used DhPKS1 as a case study and carried out its disruption through Agrobacterium-mediated transformation in the isolate 7/96. D. helianthi DhPKS1 deleted mutants were less virulent to sunflower compared to the wild type, indicating a role for this gene in the pathogenesis of the fungus.

Conclusion: The PKS sequences analysed and reported here constitute a new genomic resource that will be useful for further research on the biology, ecology and evolution of $D$. helianthi and generally of fungal plant pathogens.
\end{abstract}

Keywords: Polyketide synthases, Diaporthe helianthi, Plant pathogen, Pathogen virulence, toxins

\section{Background}

Polyketides are a large and diverse group of secondary metabolites with different biological activities, including pathogenicity, such as T-toxin produced by Cochliobolus heterostrophus [1] and melanin, a pigment essential for plant pathogenesis by many fungi $[2,3]$. Biosynthesis of these metabolites is accomplished by polyketide synthases [4]. Polyketide synthases (PKSs) are modular enzymes classified on the basis of their molecular architecture and

\footnotetext{
* Correspondence: michelina.ruocco@ipsp.cnr.it

${ }^{1}$ Istituto per la Protezione Sostenibile delle Piante, CNR-IPSP, Via Università

133, 80055 Portici (Naples), Italy

Full list of author information is available at the end of the article
}

operating mechanisms into types I, II and III [5-8]. Fungal PKs show a structural diversity that can vary from simple aromatics to highly modified complex reduced-type compounds [9]. Many fungal PKSs have an architecture based on single modular iterative type I polyketide synthases (iPKSs), containing ketosynthase (KS), acyltransferase (AT) and acyl carrier protein (ACP) domains. In addition to these, other functional domains, such as ketoreductase (KR), dehydratase (DH), enoylreductase (ER), methyltransferase $(\mathrm{MeT})$ and thioesterase (TE), may be present in PKSs [10].

Diaporthe helianthi Munt.-Cvetk., Mihaljč. \& M. Petrov (syn. Phomopsis helianthi Munt.-Cvetk., Mihaljč. \& 
M. Petrov) is a phytopathogenic fungus which causes stem canker and leaf shedding in sunflower (Helianthus annuus L.). The fungus invades and spreads through the leaves, progresses towards the petioles along foliar veins, and finally enters the stem, where cankers form in the advanced stage of pathogenesis [11]. D. helianthi is an important pathogen with a worldwide distribution. First reported in the former Yugoslavia [12], it subsequently spread to several other countries [13-15]. It can cause significant losses in yield and reduction of oil content when environmental conditions are favourable for disease development [16]. In Italy this disease has been observed since 1987, but even when climatic conditions are favourable to the disease $[17,18]$, its appearance is sporadic [19]. Epidemiological differences of this widespread disease could be explained by a high genetic diversity occurring in the $D$. helianthi populations depending on their geographic origin. Intraspecific variability has been previously displayed by isolates representative of diverse sunflower-growing areas [20-23]. All the isolates collected in France and in the former Yugoslavia, where epidemics of sunflower stem canker are severe, formed a monophyletic clade clearly distinct from all other isolates, while all the Italian isolates were phylogenetically distant from this cluster, evidencing a clear link between genetic biotype and pathogenic behaviour [21].

It has been nowadays accepted that sunflower stem canker is associated with a complex of Diaporthe species with different levels of pathogenicity. The main causal agent of the disease has been identified as D. gulyae sp. nov. in association with two less virulent species, $D$. kochmanii sp. nov. and D. kongii sp. nov. in Australia [23], whereas in the United States, D. gulyae and D. helianthi were both identified as causal agents of the disease having similar levels of aggressiveness [24].

The highly virulent French isolate 7/96 can be referred as D. helianthi sensu stricto. A DNA region of $532 \mathrm{bp}$ from this isolate, shared with all highly virulent strains but not with the Italian mildly virulent isolates, was identified and sequenced [25]. This sequence, named lovB (accession number: AJ512137) showed a high similarity to genes encoding polyketide synthases (PKSs) from several species of filamentous fungi, including $m l c A$ and $m l c B$ of Penicillium citrinum, lovB of Aspergillus terreus, fum5 of Gibberella moniliformis, pks1 of Cochliobolus heterostrophus and pks1 of G. fujikuroi.

The mechanisms of pathogenicity and symptom induction are poorly understood in D. helianthi. Mazars et al. $[26,27]$ have demonstrated the production of a polyketidic phytotoxin, named phomozin, during pathogenesis on sunflower leaves and in culture filtrates of a French $D$. helianthi strain. The purified toxin produced symptoms comparable to those caused by pathogen infection. Subsequently, Avantaggiato et al. [28] purified other two phytotoxic metabolites, identified as cis- and trans-4,6-dihydroxymellein, from cultures of French and Italian isolates with different degrees of virulence. These toxins show a structure similar to phomozin, sharing with it the same precursor, known as orsellinic acid [28].

In the present study we generated a draft genome of the highly virulent isolate D. helianthi 7/96 and annotated 40 genes coding for putative PKSs [29]. By using the Pathogen-Host Interaction database (PHI-base) (http://www.phi-base.org) [30], orthologs of genes known to be involved in biosynthesizing PKs, which are virulence factors in other fungal species, were identified. Furthermore, the role in virulence of the gene DhPHS1 $(=D$. helianthi polyketide synthase 1$)$ was evaluated through a gene disruption approach.

\section{Methods}

\section{Fungal isolate and media}

$D$. helianthi highly virulent French isolate 7/96 belongs to the fungal collection of Department of Agriculture, Food and Environment, University of di Pisa (Italy) [25] and was maintained on slants of PDA (potato dextrose agar, Difco) under mineral oil at $4{ }^{\circ} \mathrm{C}$.

\section{Diaporthe helianthi strain 7/96 draft genome sequence v2} Based on raw data available from a previous project [29], we generated a new $D$. helianthi strain 7/96 genome assembly. Paired end reads of $90 \mathrm{bp}(1.80 \mathrm{Gbp})$ were assembled using SPAdes 3.11.0 [31]. The genome of $D$. helianthi consists of 7376 sequence scaffolds with a total assembly length of $63.67 \mathrm{Mbp}$ (N50 $=20,184$ and L50 = 860), 43.99\% GC-content, and a maximum scaffold size of $151,286 \mathrm{bp}$. The completeness of the assembly was assessed using BUSCO v12 [32], which estimated the genome sequence to be $99.65 \%$ complete. The genome was annotated using the MAKER2 pipeline [33]. Overall, 13,139 protein-coding gene models were predicted.

The new genome assembly of $D$. helianthi strain 7/96 is present in GenBank with accession number: MAVT00000000.2.

\section{Genomic characterization of putative PKSs genes}

Putative PKS genes were identified according to Klarsson et al. [34] and manually inspected for conserved domain (acyl transferase [AT] - InterPro domain IPR014043, acyl carrier protein or phosphopantetheine attachment site [ACP or PP] - IPR009081, beta-ketoacyl synthase $\mathrm{N}$-terminal domain [KS-N] - IPR014030, beta-ketoacyl synthase C-terminal domain [KS-C] - IPR014031, Ketoreductase [KR] - IPR013968, polyketide synthase dehydratase [DH] - IPR020807, polyketide synthase, enoylreductase domain [ER] - IPR020843, methyltransferase $[\mathrm{MT}]$ - IPR013217, thioesterase [TE] - 
IPR001031) using InterProScan [35]. Moreover, putative $D$. helianthi PKSs sequences were aligned with references of other ascomycetes using MAFFT 7.310 [36] and a phylogenetic analysis was performed with PhyML 3.0 [34].

\section{DNA molecular techniques}

Total DNA was obtained from $D$. helianthi grown on PDA plates overlaid with a cellophane membrane. Plates were inoculated with mycelial plugs and incubated at $24{ }^{\circ} \mathrm{C}$ for 5 days. Mycelium mats were peeled from membranes, freeze-dried overnight, and used for DNA extraction according to Raeder and Broda [37].

Plasmids were purified from E. coli DH5 $\alpha$ cultures, grown on LB (yeast extract $5 \mathrm{~g} / \mathrm{L}, \mathrm{NaCl} 5 \mathrm{~g} / \mathrm{L}$, tryptone $10 \mathrm{~g} / \mathrm{L}$ ) by using QIAprep Spin Miniprep Kit (QIAGEN).

All PCR amplifications were performed as follows: initial denaturation at $94{ }^{\circ} \mathrm{C}$ for $3 \mathrm{~min}, 35$ cycles of denaturation $\left(45 \mathrm{~s}\right.$ at $\left.94{ }^{\circ} \mathrm{C}\right)$, annealing $\left(45 \mathrm{~s}\right.$ at $\left.60{ }^{\circ} \mathrm{C}\right)$ and extension $\left(1 \mathrm{~min} 50 \mathrm{~s}\right.$ at $\left.72{ }^{\circ} \mathrm{C}\right)$, and a final extension at $72{ }^{\circ} \mathrm{C}$ for $10 \mathrm{~min}$. PCR reactions were carried out in PCR buffer (Promega, Madison, WI, USA), $0.2 \mathrm{mM}$ dNTPs (Roche Applied Science, Mannheim, Germany), $0.2 \mathrm{M}$ each primer, 0.4 unit of Taq polymerase (Promega), and ca. $5 \mathrm{ng}$ of template DNA.

To amplify the complete sequence of DhPKS1 gene, PCR were performed by using Platinum ${ }^{\circ}$ Taq DNA Polymerase High Fidelity (ThermoFisher) with the primers DhPKS1for (ATGTCCAAGGCAATTTGTACTAC) and DhPKS1rev (CCTATCGCTAACAATCTTGT). The PCR cycles were as follows: initial denaturation at $95{ }^{\circ} \mathrm{C}$ for $5 \mathrm{~min}, 35$ cycles of denaturation $\left(45 \mathrm{~s}\right.$ at $\left.95{ }^{\circ} \mathrm{C}\right)$, annealing $\left(45 \mathrm{~s}\right.$ at $\left.60^{\circ} \mathrm{C}\right)$ and extension $\left(8 \mathrm{~min}\right.$ at $\left.68{ }^{\circ} \mathrm{C}\right)$, and a final extension at $68^{\circ} \mathrm{C}$ for $10 \mathrm{~min}$.

Sequence editing and analysis were carried out using BioEdit 7.0.5.2 (http://www.mbio.ncsu.edu/bioedit/bioedit.html) software and online tools available at European Bioinformatics Institute (http://www.ebi.ac.uk/).

DNA restriction, elution and ligation, and Southern blot analysis were carried out as described by [38], performing hybridization at $60{ }^{\circ} \mathrm{C}$ for $16 \mathrm{~h}$ and washing of blots in $2 \times$ SSC and 0.5 SSC at room temperature.

\section{Construction of plasmid pUR5750. $\triangle D h P K S 1$}

For $D$. helianthi transformation, the binary vector pUR5750, described by De Groot et al. [39] was used. This vector contains the neomycin phosphotransferase gene under the control of the nopaline synthase promoter and $\operatorname{trpC}$ terminator that confers resistance to kanamycin; it also carries, between the HindIII and KpnI restriction sites, the E. coli hygromycin B (hph)-resistance cassette, coding for the hygromycin B phosphotransferase enzyme $(h p h)$ under the control of the $A$. nidulans gpdA promoter and $\operatorname{trp} C$ terminator. The two flanking regions of the previously isolated sequence $\operatorname{Lov} B$ [25] were identified and cloned with GenomeWalker kit (Clontech Laboratories, Palo Alto, CA) as follows: Separate fungal DNA aliquots were digested with four different restriction enzymes (EcoRV, DraI, PvuII, StuI) leaving blunt ends and ligated to adaptors. For each fragment library, two primary PCR amplifications were carried out using an adaptor primer provided with the kit and an outer, gene-specific primer for downstream and upstream walking, $5^{\prime}$-AAG GTG GAC ACG GCA TAC CAC TCA TT-3' and 5'-CCA AGT CTT CAG CAG GAA TAT CAA CCA C-3', respectively. The primary PCR product was then diluted and used as a template for a secondary PCR amplification using a nested adaptor primer and nested gene-specific primers $\left(5^{\prime}\right.$ AGC TGC AAG TGC CTT ACC ACG GAT TAC-3' for downstream walking and 5'-ATG AGT GGT ATG CCG TGT CCA CCT TC-3' for upstream walking). The resulting DNA, flanking $\operatorname{LovB}$, of 548 and 1256 bp were singly cloned in p-GEM-T Easy vector system (Promega) to form clones and DL2, respectively. To generate pUR5750. $\triangle D h P K S 1$, the two previously cloned regions were excised from p-GEM-T Easy vector and fragments

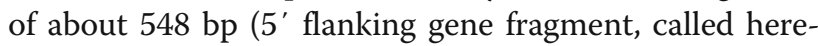
after " $\mathrm{A}$ ") and $944 \mathrm{bp}$ ( $3^{\prime}$ flanking gene fragment, called hereafter "B"), were inserted in pUR5750 KpnI and Hin$d \mathrm{III}$ restriction sites, respectively, at the sides of $(h p h)$ resistance cassette (Fig. 1).

In detail, the A fragment was excised from the plasmid by EcoRI digestion, and PCR-amplified with specific primers (5'AGGTACCATTCGATTACTATAGGGCACG $3^{\prime}$ and 5'AGGTACC GTACTCAGGCATGGAGCAAA $\left.3^{\prime}\right)$, carrying at ends the KpnI cutting site sequence. The B fragment, was excised from the plasmid pGEM-T easy by EcoRI digestion, and inserted in the EcoRI site of pBluescript KS; from this construct a smaller fragment of about 944 bp was excised, with HindIII restricion enzyme. The two DhPKS1 gene fragments (KpnI 548 bp and HindIII $944 \mathrm{bp}$ ) flanking the designed knock-out site, were inserted in the corresponding cutting-site in the plasmid pUR5750, upstream and downstream of the $h p h$ resistance cassette, to form a new plasmid named pUR5750. $\Delta$ Dhpks1. Finally, pUR5750. $\triangle D h P K S 1$ was transferred into A. tumefaciens LBA1100 by electroporation [40]; electroporation conditions were $25 \mu \mathrm{F}, 200 \Omega, 2.5 \mathrm{kV}$ (0.2 cm cuvettes) in Gene Pulser ${ }^{\circ}$ electroporator (Bio-Rad, USA), and transformants were selected on LB agar with and kanamycin $(100 \mu \mathrm{g} / \mathrm{ml})$. Agrobacterium strains containing the binary vectors were identified by PCR.

\section{Agrobacterium tumefaciens-mediated gene disruption}

The LBA1100-derived strain transformed with pUR5750. $\triangle D h P K S 1$ was grown at $28{ }^{\circ} \mathrm{C}$ for 3 days in Petri dishes containing LB medium supplemented with 


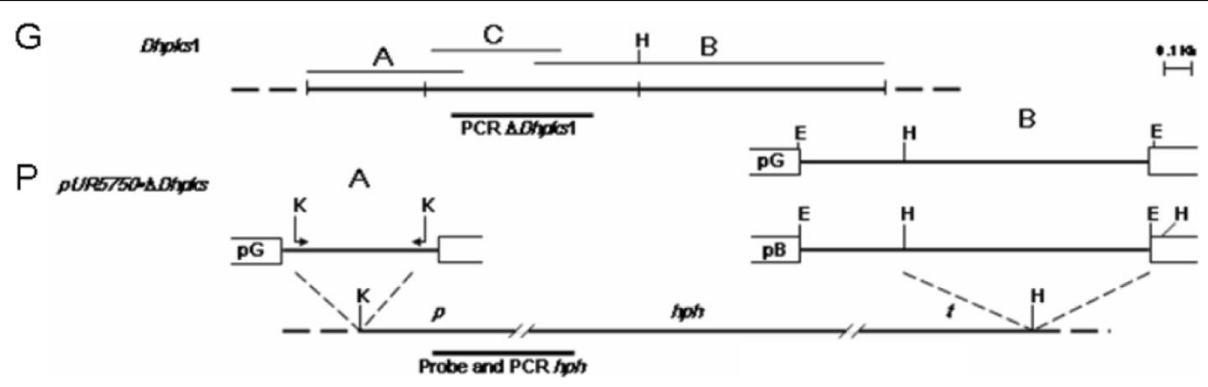

Fig. 1 (G): Restriction map (not all restriction sites are included) of the genomic fragment of Diaporthe helianthi containing the DhPKS1 gene with the original sequence isolated by Vergara et al. (2004) (C) plus its flanking gene portions (A and B) used for hygromicin phosphotransferase (HPH) gene replacement cassette construction. (P): Restriction map (not all sites are included) of plasmid pUR5750. $\triangle D h P K S 1$ containing $h p h$ gene of $E$. coli under the control of the A. nidulans gpdA promoter $(p)$ and trpc terminator $(t)$. In the construction design, pGEM-T Easy vector system ( $\mathrm{pG}$ ) and pBluescript KS (pB) were used as intermediate vectors. $\mathrm{H}=$ Hindlll; $\mathrm{K}=\mathrm{Kpnl}$; $\mathrm{E}=\mathrm{EcoRI}$

kanamycin $(100 \mu \mathrm{g} / \mathrm{ml})$. One hundred milliliter of liquid LB supplemented with kanamycin $\left(100 \mu \mathrm{g} \mathrm{ml}^{-1}\right)$ were inoculated with a single bacterial colony and incubated at $28{ }^{\circ} \mathrm{C}$ overnight on an orbital shaker at $150 \mathrm{rpm}$. Bacterial cells were harvested by centrifugation at $12000 \mathrm{~g}$ at $4{ }^{\circ} \mathrm{C}$ and resuspended in $5 \mathrm{ml}$ of IM $\left(1 \mathrm{mM} \mathrm{KH} \mathrm{KO}_{4} \mathrm{pH} 4.8 ; 2.4 \mathrm{mM}\right.$ $\mathrm{MgSO}_{4} \cdot 7 \mathrm{H}_{2} \mathrm{O} ; 5 \mathrm{mM} \mathrm{NaCl} ; 0.068 \mathrm{mM} \mathrm{CaCl} 2 ; 0.003 \mathrm{mM}$ $\mathrm{FeSO}_{4} \cdot 7 \mathrm{H}_{2} \mathrm{O} ; 0.0015 \mathrm{mM} \mathrm{ZnSO}{ }_{4} \cdot 7 \mathrm{H}_{2} \mathrm{O} ; 0.002 \mathrm{mM} \mathrm{CuSO}_{4}$ $5 \mathrm{H}_{2} \mathrm{O} ; 0.008 \mathrm{mM} \quad \mathrm{H}_{3} \mathrm{BO}_{3} ; 0.003 \mathrm{mM} \quad \mathrm{MnSO}_{4} \cdot \mathrm{H}_{2} \mathrm{O}$; $0.002 \mathrm{mM} \mathrm{Na} 2 \mathrm{MoO}_{4} \cdot 2 \mathrm{H}_{2} \mathrm{O} ; 6.25 \mathrm{mM} \mathrm{NH} \mathrm{NO}_{3} ; 54.2 \mathrm{mM}$ glycerol; $40 \mathrm{mM}$ 2-(N-morpholino)ethanesulfonic acid; $0.05 \mathrm{mM}$ glucose). The bacterial suspension was distributed in aliquots of $1 \mathrm{ml}$ and further incubated at $30{ }^{\circ} \mathrm{C}$ for $6 \mathrm{~h}$ under stirring. Cultures of the fungal isolate $7 / 96 \mathrm{~b}$ were grown on IM-agar supplemented with acetosyringone (AS, $0.2 \mathrm{mM}$ ) and incubated at $24{ }^{\circ} \mathrm{C}$. After $4-5$ days, mycelial plugs of these colonies were used to inoculate $10 \mathrm{ml}$ of liquid IM + AS. The cultures were then incubated for 4 days at $24{ }^{\circ} \mathrm{C}$ under gentle stirring and periodically vortexed for $5 \mathrm{~min}$. The mycelium was recovered by centrifugation at $4000 \mathrm{~g}$ for $15 \mathrm{~min}$ and re-suspended in $5 \mathrm{ml}$ of IM + AS.

For co-cultivation, $1 \mathrm{ml}$ of mycelial suspension was mixed with an equal volume of bacterial suspension at $24{ }^{\circ} \mathrm{C}$ and stirred for about $20 \mathrm{~min}$. The mix was plated onto nitrocellulose filters on a co-cultivation medium (IM-agar + AS) and incubated at $24{ }^{\circ} \mathrm{C}$ for 3 days. After growth on co-cultivation medium, the filters were transferred to PDA amended with hygromycin $(25 \mu \mathrm{g} / \mathrm{ml})$ as selective medium for fungal transformants and cefotaxime $(200 \mu \mathrm{M})$ to inhibit growth of A. tumefaciens, and incubated at $24{ }^{\circ} \mathrm{C}$ for 20 days. Hygromicin resistant colonies were purified by three successive hyphal transfers on PDA supplemented with $100 \mu \mathrm{g} / \mathrm{ml}$ hygromicin to select hyphae containing only transformed nuclei. The analysis of transformants was performed by PCR using specific primers designed to amplify both hygromicin resistance cassette (hph2for: 5'-ATGGCAACAAATGTTGGACTG-3'; gpdArev: 5'-CAAGGAGGAGTAAGCTCCTT3'), and DhPKS1 gene replacement site (Dhpks537for: 5'-
GTACTCCAAGGCTTTATCGC-3'; Dhpks1326rev: 5'TGATGTAGAACTGGGCCACA-3') of $D$. helianthi. As control, $D$. helianthi mutants containing pUR5750 empty vector insertion were obtained.

Single copy insertion was verified by Southern blot analysis of genomic DNA digested with SpeI and BglII restriction enzymes, which do not cut in the Agrobacterium-transferred construct. Hybridization was carried out with digoxigenin-labelled probe obtained by PCR-amplification of binary vector pUR5750 DDPRS1 plasmidic DNA using hph2for - gpdArev primers. D. helianthi wild type DNA and PCR-amplified construct $\triangle D h P K S 1$ containing the hygromycin B (hph)-resistance cassette, were used as negative and positive controls, respectively.

\section{Phytotoxicity and virulence assays}

For phytotoxicity tests, mycelial plugs from actively growing colonies of $D$. helianthi isolate $7 / 96$ and transformants were grown, in static condition, on liquid medium in $2 \mathrm{~L}$ volume Erlenmeyer flasks containing $1 \mathrm{~L}$ of substrate made with: $3 \mathrm{~g} / \mathrm{L}$ L-asparagine, $15 \mathrm{~g} / \mathrm{L}$ sucrose, $1 \mathrm{~g} / \mathrm{L} \quad \mathrm{K}_{2} \mathrm{HPO}_{4}, 0.5 \mathrm{~g} / \mathrm{L} \quad \mathrm{MgSO}_{4} 7 \mathrm{H}_{2} \mathrm{O}, 0.5 \mathrm{~g} / \mathrm{L}$ $\mathrm{KCl}, 0.018 \mathrm{~g} / \mathrm{L} \mathrm{FeSO}_{4} 7 \mathrm{H}_{2} \mathrm{O}, 5 \mathrm{~g} / \mathrm{L}$ fresh sunflower tissue. The same liquid medium without fungal inoculation was used as a control. After 28 days, the liquid cultures were vacuum filtered, sterilised through Millipore filters of $0.2 \mu \mathrm{m}$ and used in phytotoxicity tests, performed with cuttings of 15-day-old sunflower seedlings according to Avantaggiato et al. [28]. Ten sunflower cuttings were used per experiment and the experiment was replicated three times.

For virulence tests inoculum was prepared by growing D. helianthi strain $7 / 96$ and transformants in Petri dishes containing different parts of sunflower (stems, leaves and flowers). Fresh plant tissues, surface sterilized with sodium hypochlorite $(2.5 \% / \mathrm{vol}$.) and washed in sterile water, were dried, chopped $(250 \mathrm{~g} / \mathrm{L})$ and mixed with agar $(15 \mathrm{~g} / \mathrm{L})$. The fungus inoculated on the sunflower- 
agar substrate was left to grow in the dark for 1 week at $25{ }^{\circ} \mathrm{C}$. Seventy-eight-day-old sunflower plants (very susceptible cv Ala) at the flower bud stage were inoculated by placing a mycelial plug both on the upper surface of leaves and at the insertion point of the leaf petiole (sticking with a wooden toothpick). The diseased area was measured recording two diameters of the necrotic spot, by using a digital caliper. Inoculated plants were kept in a moist chamber for 7 days at $24{ }^{\circ} \mathrm{C}$. The bioassay was carried out on five plants for each fungal strain and was repeated twice. Data were analysed by ANOVA test with Welsch modification, because data were normally distributed but not homoscedastic. Different means were separated by T3 Dunnett test. Statistical analyses were performed by SPSS 20.0 software.

\section{Results}

\section{PKS genes in Diaporthe helianthi genome}

By searching the draft nuclear genome of $D$. helianthi isolate 7/96 [29], we found a large number of putative PKS homologues which have been deposited in GenBank (Additional file 1). Most PKS genes coded by $D$. helianthi were reducing PKSs, whereas only eight PKSs lacked reducing domains and clustered with nonreducing PKSs (Additional file 1). DhPKS8, DhPKS18, DhPKS27 proteins did not cluster into any of the clades indicated in Fig. 2. DhPKS1 was placed in nonribosomal peptide synthetase (NRPS)-PKS clade, with the closest sequence being ATEG_00325 protein from A. terreus involved in isoflavipucine biosynthesis.

\section{Homologies of DhPKSs with other genes involved in host- pathogen interaction}

By whole genome sequencing of $D$. helianthi, we were able to decipher the complete sequence of all DhPKS genes and in silico deduced amino acid sequences (Additional file 1). Through a PHI-base interrogation we identified homologs for all DhPKS genes, except for two (DhPKS11 and DhPKS35), with experimentally verified pathogenicity, virulence and effector genes from fungal, oomycete and bacterial pathogens, infecting animal, plant, fungal and insect hosts. Results of this search are reported in Table 1.

\section{Replacement of DhPKS1}

Using oligonucleotides designed at $5^{\prime}$ and $3^{\prime}$ ends of genomic sequence of DhPKS1 we sequenced the complete gene (7877 bp) confirming its in silico prediction. In silico analysis showed that the coded protein corresponded to a highly reducing (HR) type I iPKS, containing the full set of domains, ketoacyl synthase (KS), acyl transferase, (AT), ketoreductase (KR), dehydratase (DH) and acyl carrier protein (ACP) (Additional file 1). Due to the identity of DhPKS1 with $\operatorname{lovB}$ (AN
AJ512137) fragment identified by Vergara et al. [25] we decided to test its potential involvement in pathogenicity of $D$. helianthi.

Transformation of $D$. helianthi 7/96 with the gene disruption cassette in DhPKS1 yielded 160 hygromicinresistant colonies. These putative transformants were purified by successive transfers of mono-hyphal and single protoplasts to selective medium amended with hygromycin $100 \mu \mathrm{g} / \mathrm{L}$. Hygromycin resistance of transformants was not lost upon successive transfers; 74 of the hygromicin resistant colonies were screened by two PCR analyses. The first PCR was performed on the genomic DNA of each transformant, with the hph2for trpc2rev primers specific to amplify the hygromicin resistance cassette (Fig. 3). Hph-containing transformants were then screened with a second PCR, to verify the homologous integration of the construct. In this case, we used Dhpks537for - Dhpks1326rev primers, designed on sequences internal to the replacement site of DhPKS1 (Fig. 4). This second PCR showed that 13 out of the 74 (18\%) transformants integrated the $\triangle D h P K S 1$ construct at the homologous site. The number of integrated copies of the construct in the genome of $D$. helianthi transformants was ascertained by Southern blot analysis with a probe specific for the hygromicin-resistance cassette (Fig. 5). Single copy integration of the construct occurred in five transformants designated as $\operatorname{Tr} 1-5$, as the enzymes used for genomic DNA digestion do not cut the Agrobacterium-transferred construct.

\section{Phytotoxicity and virulence bioassays}

$\triangle D h P K S 1$ mutants showed regular in vitro development and their growth rates were not significantly different from that of the wild type. Sunflower cuttings steeped in liquid cultures of the $D$. helianthi isolate 7/96 showed, after 5 days, brown marginal necrotic lesions and leaf chlorosis attributable to filtrate phytotoxicity. Cuttings steeped in culture extracts of DhPKS1 knock-out mutants, did not show clear evidence of phytotoxicity (Fig. 6).

Inoculation of sunflower plants with $D$. helianthi strain 7/96 wild type resulted in typical symptoms of stem canker disease when observed 20 days after inoculation (Fig. 7a). Plants inoculated with transformants showed less intense symptoms (Fig. 7b). The disease severity in terms of necrotic area was measured in $\mathrm{cm}^{2}$ on leaf blade and stem, in sunflower plants inoculated with the parental strain and transformants. For each time point, infection was markedly less severe with $\triangle D h P K S 1 \mathrm{mu}-$ tant than with the other strains. In particular the average necrotic area $\left(\mathrm{cm}^{2}\right)$ at $84 \mathrm{~h}$ was $1.3 \pm 0.28,8.0 \pm 1.65$ and $8.5 \pm 1.56$, for $\triangle D h P K S 1$, wild type and empty vector transformant strains, respectively (Fig. 7c). 


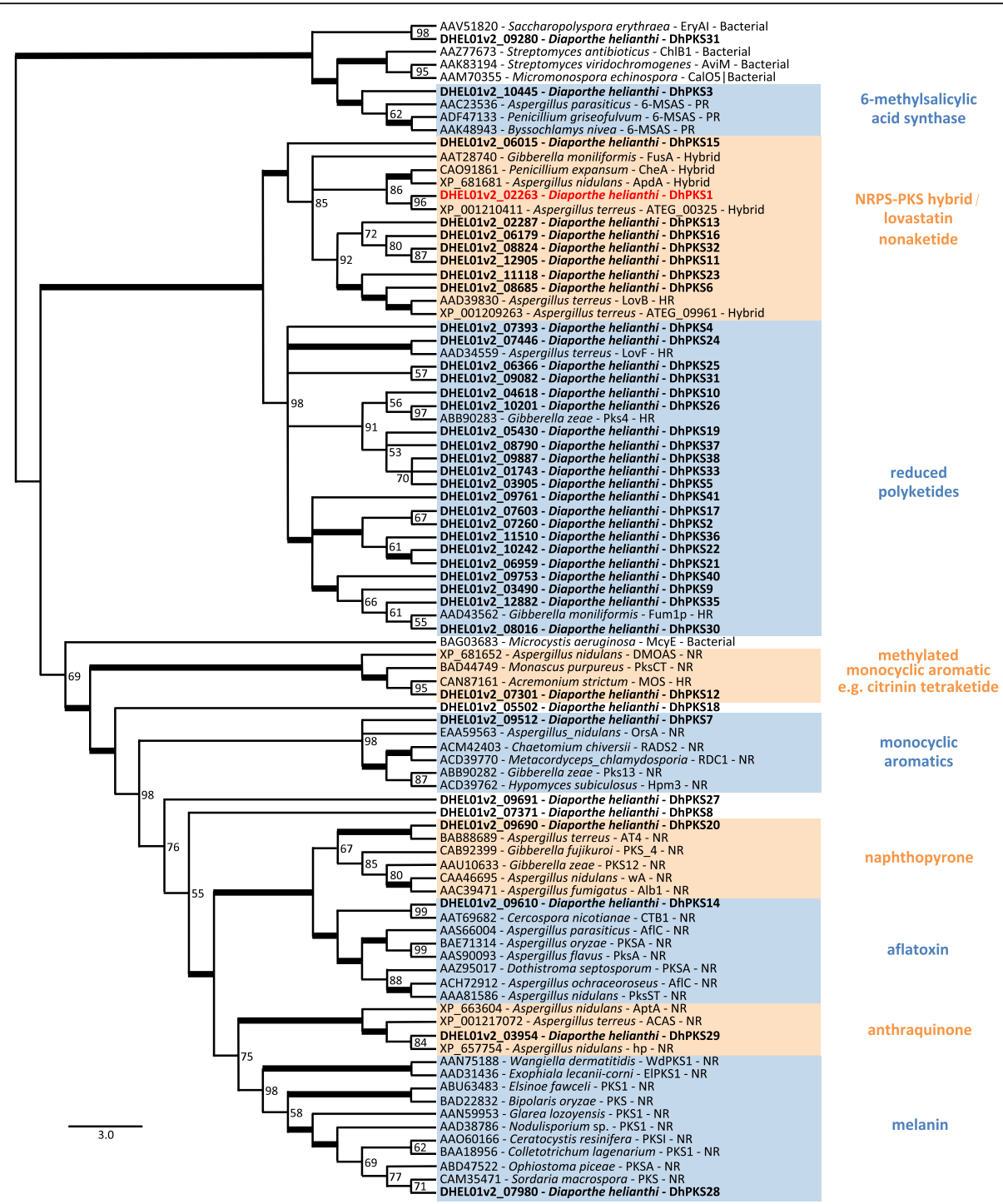

Fig. 2 Phylogenetic tree of Diaporthe helianthi PKSs proteins (highlighted in bold) and reference PKSs from other fungi based on Karlsson et al., [34] . DhPKS1 used for molecular characterization is highlighted in red. Numbers next to the nodes represent bootstrap values. Full $D$. helianthi PKS genes information is provided in Additional file 1

\section{Discussion}

The management of sunflower stem canker requires the identification of diverse species of Diaporthe associated with it, the determination of their aggressiveness and the study of pathogenicity mechanisms. In this paper we analysed the genome of the highly aggressive isolate $7 /$ 96 of D. helianthi, regarded as the main causal agent of sunflower stem canker epidemics in Europe [25], on the basis of its putative polyketide synthase genes. We found in its genome at least 40 PKS genes, more than those reported in other ascomycetes: 15 in G. moniliformis, 16 in G. zeae, 20 in B. cinerea, 25 in C. heterostrophus [41] and 27 in Aspergillus nidulans [42]. Such a repertoire of PKSs makes possible the synthesis of almost all known types of polyketide compounds by D. helianthi 7/96.
The PHI-base search demonstrated that all the putative 40 PKS proteins found in D. helianthi, with the exception of DhPKS11 and DhPKS35, have at least one ortholog in other pathogenic fungi or bacteria (Table 1). The majority of the reported orthologous genes have been demonstrated to be important factors in pathogenicity or virulence by gene deletion experiments.

A fragment of $L o v B$-like coding sequence was isolated by Vergara et al. [25] from the genome of the aggressive isolate of $D$. helianthi $7 / 96$, and proved to be present in the genome of the most aggressive isolates of $D$. helianthi, such as the French and Yugoslavian ones. In the present work this gene, named DhPKS1, was fully characterized. In silico sequence analysis revealed that DhPKS1 belongs to subclade II of type I reducing PKS 
Table 1 List of all DhPKS genes, with the exclusion of two (DhPKS11 and DhPKS35), with experimentally verified pathogenicity, virulence and effector genes from fungal, oomycete and bacterial pathogens, which infect animal, plant, fungal and insect hosts, obtained by searching PHI-base (http://www.phi-base.org)

\begin{tabular}{|c|c|c|c|c|c|c|c|c|c|}
\hline \multicolumn{10}{|c|}{ PHI Closest hits (proteins) } \\
\hline Name & $\begin{array}{l}\text { GenBank Acc. } \\
\text { Num. }\end{array}$ & $\begin{array}{l}\text { Putative protein } \\
\text { length (aa) }\end{array}$ & Organism & Disease & $\begin{array}{l}\text { Protein } \\
\text { name }\end{array}$ & $\begin{array}{l}\text { Protein } \\
\text { ID }\end{array}$ & $\begin{array}{l}\text { Identity } \\
(\%)\end{array}$ & $\begin{array}{l}\text { Similarity } \\
(\%)\end{array}$ & Ref. \\
\hline \multirow[t]{3}{*}{ DhPKS1 } & KR153185 & 2501 & M. oryzae & Rice blast & ACE1 & Q6ZX14 & 33.98 & 50.56 & {$[50]$} \\
\hline & & & B. cinerea & Gray mould & $\mathrm{BcBOA6}$ & B1GVX7 & 34.76 & 53.57 & [44] \\
\hline & & & A. brassicicola & Black spot & DEP5 & D2E9X0 & 32.68 & 50.45 & [52] \\
\hline \multirow[t]{2}{*}{ DhPKS2 } & KR153184 & 2635 & G. fujikuroi & Foolish seedling & $\begin{array}{l}\text { FUM1 } \\
\text { (FUM5) }\end{array}$ & Q9Y8A2 & 32.53 & 49.48 & [66] \\
\hline & & & $\begin{array}{l}\text { C. } \\
\text { heterostrophus }\end{array}$ & Leaf blight & PKS1 & Q92217 & 31.58 & 48.37 & [3] \\
\hline DHPKS3 & KR153183 & 1798 & A. oligospora & Nematophagous fungus & AoMls & G1XLT2 & 46.59 & 63.93 & [67] \\
\hline \multirow[t]{2}{*}{ DHPKS4 } & KR153182 & 3071 & F. verticillioides & Ear and stalk rot of maize & FVEG_12528 & W7NCN7 & 28.69 & 45.46 & [68] \\
\hline & & & $\begin{array}{l}F . \\
\text { graminearum }\end{array}$ & Fusarium ear blight & PKS4 (ZEA1) & Q2VLJ2 & 28.14 & 45.46 & [69] \\
\hline \multirow[t]{2}{*}{ DHPKS5 } & KR153181 & 2585 & $\begin{array}{l}\text { C. } \\
\text { heterostrophus }\end{array}$ & Leaf blight & PKS1 & Q92217 & 33.22 & 51.15 & [3] \\
\hline & & & G. fujikuroi & Foolish seedling & $\begin{array}{l}\text { FUM1 } \\
\text { (FUM5) }\end{array}$ & Q9Y8A2 & 31.92 & 48.97 & [66] \\
\hline \multirow[t]{2}{*}{ DHPKS6 } & KR153180 & 3013 & M. oryzae & Rice blast & ACE1 & Q6ZX14 & 35.17 & 53.24 & [50] \\
\hline & & & B. cinerea & Gray mould & $\mathrm{BcBOA6}$ & B1GVX7 & 38.13 & 56.32 & [44] \\
\hline \multirow[t]{3}{*}{ DHPKS7 } & KR153179 & 2140 & C. graminicola & maize anthracnose & CgPKS1 & C9W7X1 & 32.98 & 49.38 & [70] \\
\hline & & & $\begin{array}{l}\text { F. } \\
\text { graminearum }\end{array}$ & Fusarium ear blight & $\begin{array}{l}\text { PKS13 } \\
\text { (ZEA2) }\end{array}$ & Q2VLJ3 & 36.24 & 55.66 & [71] \\
\hline & & & A. alternata & Leaf spot & ACRTS2 & F8R4Y0 & 36.75 & 53.86 & [63] \\
\hline \multirow[t]{6}{*}{ DHPKS8 } & KR153178 & 2193 & A. alternata & Leaf spot & ACRTS2 & F8R4YO & 38.87 & 55.41 & [63] \\
\hline & & & C. neoformans & $\begin{array}{l}\text { Facultative plant and animal } \\
\text { fungal pathogen }\end{array}$ & $C \ln 1$ & J9W14 & 38.57 & 55.52 & [72] \\
\hline & & & A. fumigatus & Respiratory disease & ALB1 & O59897 & 38.17 & 56.14 & [73] \\
\hline & & & A. fumigatus & Respiratory disease & PKSP & 060026 & 38.08 & 56.09 & [74] \\
\hline & & & C. lagenarium & Anthracnose & PKS1 & P79068 & 37.07 & 54.01 & [62] \\
\hline & & & E. dermatitidis & Phaeohyphomycosis & WdPKS1 & Q9Y7A7 & 36.64 & 53.72 & [75] \\
\hline DHPKS9 & KR153177 & 2519 & G. fujikuroi & Foolish seedling & $\begin{array}{l}\text { FUM1 } \\
\text { (FUM5) }\end{array}$ & Q9Y8A2 & 34.21 & 51.88 & [66] \\
\hline \multirow[t]{2}{*}{ DHPKS10 } & KR153176 & 2209 & F. verticillioides & Ear and stalk rot of maize & FVEG_12528 & W7NCN7 & 38.91 & 54.24 & [68] \\
\hline & & & $\begin{array}{l}\text { C. } \\
\text { heterostrophus }\end{array}$ & Leaf blight & PKS1 & Q92217 & 38.05 & 54.73 & [3] \\
\hline DhPKS11 & KR153175 & 171 & & & & & & & \\
\hline DHPKS12 & KR153174 & 2492 & A. alternata & Leaf spot & ACRTS2 & F8R4YO & 31.21 & 47.02 & [63] \\
\hline \multirow[t]{2}{*}{ DHPKS13 } & KR153173 & 4088 & M. oryzae & Rice blast & ACE1 & Q6ZX14 & 39.13 & 57.03 & [50] \\
\hline & & & B. cinerea & Gray mould & $\mathrm{BcBOA6}$ & B1GVX7 & 39.88 & 57.66 & [44] \\
\hline \multirow[t]{6}{*}{ DHPKS14 } & KR153172 & 2191 & A. fumigatus & Respiratory disease & ALB1 & O59897 & 42.51 & 60.58 & [73] \\
\hline & & & A. fumigatus & Respiratory disease & PKSP & 060026 & 42.46 & 60.48 & [74] \\
\hline & & & C. nicotianae & Leaf spot & CTB1 & Q6DQW3 & 42.97 & 59.11 & [64] \\
\hline & & & C. sativus & Spot blotch disease & PKS1 & G8DNT0 & 39.75 & 58.54 & [76] \\
\hline & & & A. alternata & Leaf spot & ACRTS2 & F8R4YO & 39.62 & 57.97 & [63] \\
\hline & & & C. neoformans & $\begin{array}{l}\text { Facultative plant and animal } \\
\text { fungal pathogen }\end{array}$ & $C \ln 1$ & J9W14 & 38.06 & 56.65 & [72] \\
\hline
\end{tabular}


Table 1 List of all DhPKS genes, with the exclusion of two (DhPKS11 and DhPKS35), with experimentally verified pathogenicity, virulence and effector genes from fungal, oomycete and bacterial pathogens, which infect animal, plant, fungal and insect hosts, obtained by searching PHI-base (http://www.phi-base.org) (Continued)

\begin{tabular}{|c|c|c|c|c|c|c|c|c|c|}
\hline \multicolumn{10}{|c|}{ PHI Closest hits (proteins) } \\
\hline Name & $\begin{array}{l}\text { GenBank Acc. } \\
\text { Num. }\end{array}$ & $\begin{array}{l}\text { Putative protein } \\
\text { length (aa) }\end{array}$ & Organism & Disease & $\begin{array}{l}\text { Protein } \\
\text { name }\end{array}$ & $\begin{array}{l}\text { Protein } \\
\text { ID }\end{array}$ & $\begin{array}{l}\text { Identity } \\
(\%)\end{array}$ & $\begin{array}{l}\text { Similarity } \\
(\%)\end{array}$ & Ref. \\
\hline $\begin{array}{l}\text { DHPKS15 } \\
\text { (partial) }\end{array}$ & KR153171 & 1613 & B. cinerea & Gray mould & $\mathrm{BcBOA6}$ & B1GVX7 & 34.61 & 50.99 & [44] \\
\hline \multirow[t]{2}{*}{ DHPKS16 } & KR153170 & 3886 & M. oryzae & Rice blast & ACE1 & Q6ZX14 & 34.17 & 52.24 & [50] \\
\hline & & & B. cinerea & Gray mould & $\mathrm{BcBOA6}$ & B1GVX7 & 33.69 & 52.09 & [44] \\
\hline \multirow[t]{2}{*}{ DHPKS17 } & KR153169 & 2616 & G. fujikuroi & Foolish seedling & $\begin{array}{l}\text { FUM1 } \\
\text { (FUM5) }\end{array}$ & Q9Y8A2 & 31.55 & 48.7 & {$[66]$} \\
\hline & & & A. brassicicola & Black spot & DEP5 & D2E9X0 & 36.67 & 53.72 & [52] \\
\hline DHPKS18 & KR153168 & 2161 & $\begin{array}{l}F . \\
\text { graminearum }\end{array}$ & Fusarium ear blight & $\begin{array}{l}\text { PKS13 } \\
\text { (ZEA2) }\end{array}$ & Q2VLJ3 & 29.11 & 45.31 & [71] \\
\hline DHPKS19 & KR153167 & 2647 & G. fujikuroi & Foolish seedling & $\begin{array}{l}\text { FUM1 } \\
\text { (FUM5) }\end{array}$ & Q9Y8A2 & 32.46 & 50.09 & [66] \\
\hline DHPKS20 & KR153166 & 1996 & A. fumigatus & Respiratory disease & ALB1 & O59897 & 44.37 & 60.66 & [73] \\
\hline $\begin{array}{l}\text { DHPKS21 } \\
\text { (partial) }\end{array}$ & KR153165 & 814 & A. brassicicola & Black spot & DEP5 & D2E9X0 & 41.09 & 57.14 & [52] \\
\hline DHPKS22 & KR153164 & 2505 & A. brassicicola & Black spot & DEP5 & D2E9X0 & 32.25 & 50.16 & {$[52]$} \\
\hline $\begin{array}{l}\text { DHPKS23 } \\
\text { (partial) }\end{array}$ & KR153163 & 7787 & B. cinerea & Gray mould & $\mathrm{BcBOA6}$ & B1GVX7 & 53.44 & 68.48 & [37] \\
\hline DHPKS24 & KR153162 & 2545 & $\begin{array}{l}\text { C. } \\
\text { heterostrophus }\end{array}$ & Leaf blight & PKS1 & Q92217 & 32.44 & 50.48 & [3] \\
\hline \multirow[t]{3}{*}{ DHPKS25 } & KR153161 & 2590 & F. verticillioides & Ear and stalk rot of maize & FVEG_12528 & W7NCN7 & 35.75 & 53.85 & [68] \\
\hline & & & $\begin{array}{l}F . \\
\text { graminearum }\end{array}$ & Fusarium ear blight & PKS4 (ZEA1) & Q2VLJ2 & 34.1 & 50.4 & [71] \\
\hline & & & $\begin{array}{l}\text { C. } \\
\text { heterostrophus }\end{array}$ & Leaf blight & PKS1 & Q92217 & 32.44 & 50.48 & [3] \\
\hline \multirow[t]{3}{*}{ DHPKS26 } & KR153160 & 2543 & $\begin{array}{l}\text { F. } \\
\text { graminearum }\end{array}$ & Fusarium ear blight & PKS4 (ZEA1) & Q2VLJ2 & 36.73 & 53.29 & [71] \\
\hline & & & F. verticillioides & Ear and stalk rot of maize & FVEG_12528 & W7NCN7 & 34.6 & 51.13 & [68] \\
\hline & & & $\begin{array}{l}\text { C. } \\
\text { heterostrophus }\end{array}$ & Leaf blight & PKS1 & Q92217 & 36.7 & 52.34 & [3] \\
\hline DHPKS27 & KR153159 & 2064 & A. alternata & Leaf spot & ACRTS2 & F8R4YO & 47.12 & 64.5 & [63] \\
\hline \multirow[t]{4}{*}{ DHPKS28 } & KR153158 & 2169 & C. lagenarium & Anthracnose & PKS1 & P79068 & 71.73 & 83.2 & [62] \\
\hline & & & C. graminicola & maize anthracnose & CgPKS1 & C9W7X1 & 32.98 & 49.38 & [70] \\
\hline & & & C. sativus & Spot blotch disease & PKS1 & G8DNT0 & 47.89 & 65.35 & [76] \\
\hline & & & A. alternata & Leaf spot & ACRTS2 & F8R4Y0 & 47.12 & 64.5 & [63] \\
\hline \multirow[t]{2}{*}{ DHPKS29 } & KR153157 & 1813 & P. nodorum & Septoria nodorum blotch & SnPKS19 & Q0TX07 & 45.31 & 61.45 & [77] \\
\hline & & & C. graminicola & maize anthracnose & CgPKS1 & C9W7X1 & 32.98 & 49.38 & [70] \\
\hline \multirow[t]{2}{*}{ DHPKS30 } & KR153156 & 2624 & G. fujikuroi & Foolish seedling & $\begin{array}{l}\text { FUM1 } \\
\text { (FUM5) }\end{array}$ & Q9Y8A2 & 41.46 & 57.69 & [66] \\
\hline & & & A. brassicicola & Black spot & DEP5 & D2E9X0 & 36.4 & 53.12 & [52] \\
\hline DHPKS31 & KR153155 & 2753 & A. oligospora & Nematophagous fungus & AoMls & G1XLT2 & 46.59 & 63.93 & [67] \\
\hline \multirow[t]{2}{*}{ DHPKS32 } & KR153154 & 2484 & M. oryzae & Rice blast & ACE1 & Q6ZX14 & 39.74 & 56.57 & [50] \\
\hline & & & B. cinerea & Gray mould & $\mathrm{BcBOA6}$ & B1GVX7 & 37.15 & 55.25 & [44] \\
\hline DHPKS33 & KR153153 & 2254 & G. fujikuroi & Foolish seedling & $\begin{array}{l}\text { FUM1 } \\
\text { (FUM5) }\end{array}$ & Q9Y8A2 & 28.72 & 45.55 & [66] \\
\hline DHPKS34 & KR153152 & 2365 & $\begin{array}{l}\text { C. } \\
\text { heterostrophus }\end{array}$ & Southern corn leaf blight & PKS2 & Q6RKG2 & 32.00 & 49.87 & [1] \\
\hline
\end{tabular}


Table 1 List of all DhPKS genes, with the exclusion of two (DhPKS11 and DhPKS35), with experimentally verified pathogenicity, virulence and effector genes from fungal, oomycete and bacterial pathogens, which infect animal, plant, fungal and insect hosts, obtained by searching PHI-base (http://www.phi-base.org) (Continued)

\begin{tabular}{|c|c|c|c|c|c|c|c|c|c|}
\hline \multicolumn{10}{|c|}{ PHI Closest hits (proteins) } \\
\hline Name & $\begin{array}{l}\text { GenBank Acc. } \\
\text { Num. }\end{array}$ & $\begin{array}{l}\text { Putative protein } \\
\text { length (aa) }\end{array}$ & Organism & Disease & $\begin{array}{l}\text { Protein } \\
\text { name }\end{array}$ & $\begin{array}{l}\text { Protein } \\
\text { ID }\end{array}$ & $\begin{array}{l}\text { Identity } \\
(\%)\end{array}$ & $\begin{array}{l}\text { Similarity } \\
(\%)\end{array}$ & Ref. \\
\hline & & & $\begin{array}{l}\text { C. } \\
\text { heterostrophus }\end{array}$ & Leaf blight & PKS1 & Q92217 & 36.83 & 54.98 & [3] \\
\hline & & & F. verticillioides & Ear and stalk rot of maize & FVEG_12528 & W7NCN7 & 36.16 & 53.24 & [68] \\
\hline & & & $\begin{array}{l}\text { F. } \\
\text { graminearum }\end{array}$ & Fusarium ear blight & PKS4 (ZEA1) & Q2VLJ2 & 35.14 & 52.15 & [71] \\
\hline DhPKS35 & KR153151 & 441 & & & & & & & \\
\hline DHPKS36 & KR153150 & 2422 & A. brassicicola & Black spot & DEP5 & D2E9X0 & 51.48 & 66.93 & [52] \\
\hline \multirow[t]{2}{*}{ DHPKS37 } & KR153149 & 2597 & $\begin{array}{l}\text { C. } \\
\text { heterostrophus }\end{array}$ & Leaf blight & PKS1 & Q92217 & 34.46 & 53.1 & [3] \\
\hline & & & G. fujikuroi & Foolish seedling & $\begin{array}{l}\text { FUM1 } \\
\text { (FUM5) }\end{array}$ & Q9Y8A2 & 33.81 & 51.81 & [66] \\
\hline DHPKS38 & KR153148 & 2652 & $\begin{array}{l}\text { C. } \\
\text { heterostrophus }\end{array}$ & Leaf blight & PKS1 & Q92217 & 32.04 & 49.81 & [3] \\
\hline DHPKS39 & KR153147 & 2511 & G. fujikuroi & Foolish seedling & $\begin{array}{l}\text { FUM1 } \\
\text { (FUM5) }\end{array}$ & Q9Y8A2 & 38.11 & 56.07 & [66] \\
\hline \multirow[t]{2}{*}{ DHPKS40 } & KR153146 & 2380 & A. brassicicola & Black spot & DEP5 & D2E9X0 & 30.69 & 47.58 & [52] \\
\hline & & & F. verticillioides & Ear and stalk rot of maize & FVEG_12528 & W7NCN7 & 33.2 & 50.3 & [68] \\
\hline
\end{tabular}

[41], having the typical conserved domain of this protein family KS-AT-DH-(ME)KR-PP-(CON)-(AMP-PP). Reducing PKS subclade II is characterized by enzymes missing the ER domain; PKs synthesized by PKSs of this subclade are predicted to either lack reduced alkyl groups or to contain alkyl groups whose reduction is completed by the product of an external ER domaincontaining gene, as A. terreus lovC [43] and P. citrinum mlcG. The PKSs of this clade were also found to have either a condensation (CON) domain typical of nonribosomal peptide synthetases (NPSs) [43] or an entire NPS module consisting of a CON domain, and an acyl carrier

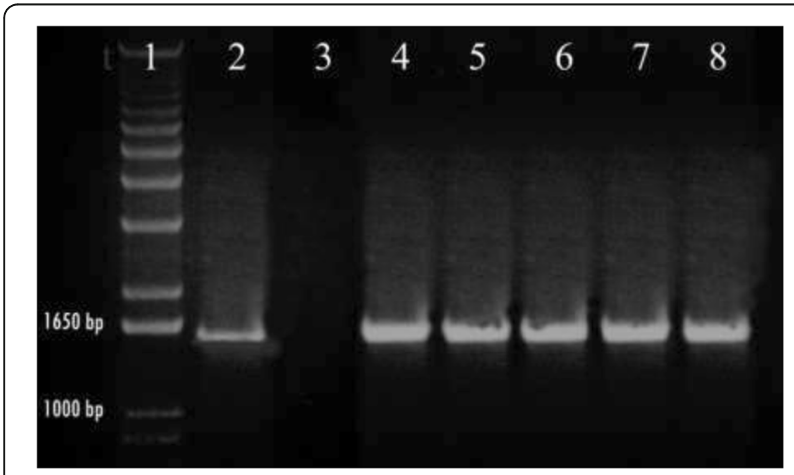

Fig. 3 PCR analysis of Diaporthe helianthi strain 7/96 (lane 3) and $\triangle \mathrm{DhPKS1}$ putative transformants (lanes 4-8) with hph2-for/trpc2-rev primers. Lanes 1 and 2 correspond to $1 \mathrm{~kb}$ molecular weight ladder and positive control, respectively or phosphopantetheine attachment site (ACP or $\mathrm{PP}$ ) domain. The absence of a DhPKS1 homologous gene in the less aggressive Italian isolates prompted us to further investigate the possible significance of this gene as a virulence determinant. Results from PHI-base search revealed that DHPKS1 is very similar to PKSs from filamentous fungi known to be involved in the production of important pathogenicity factors. Among these, it showed $35 \%$ identity with BcPKS6 gene of B. cinerea which encodes a key enzyme for botcinic acid biosynthesis, a phytotoxin involved in virulence of the fungus on tomato [44]. Moreover, BcPKS6 belongs to a PKS cluster co-regulated by the Go subunit BCG1, which, in turn, is essential for pathogenicity of $B$. cinerea on bean

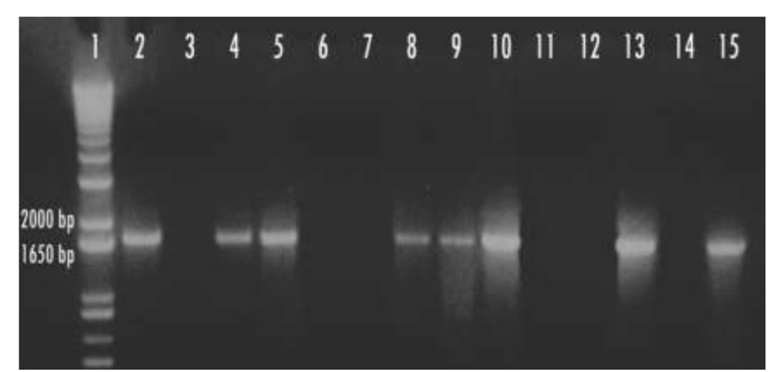

Fig. 4 PCR analysis of Diaporthe helianthi strain 7/96 (lane 2) and $\triangle$ DhPKS1 putative transformants (lanes 4-15) with Dhpks537-for/ Dhpks1326-rev primers. Lanes 1 and 3 correspond to $1 \mathrm{~kb}$ molecular weight ladder and negative control, respectively 


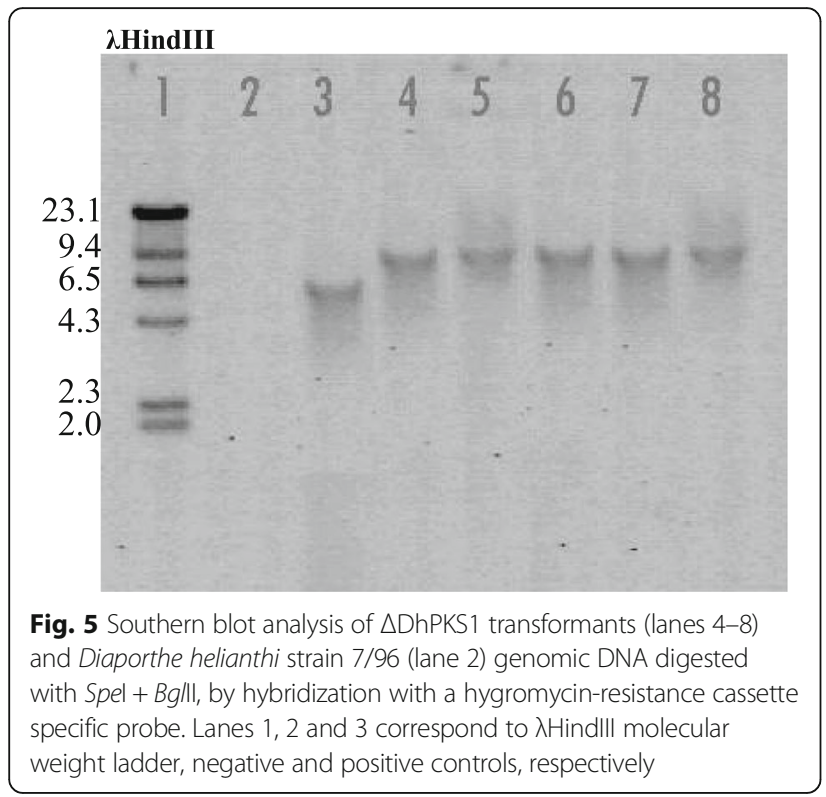

leaves [45] and is part of a clade including several PKSs responsible for the synthesis of cyclic polyketides like: LovB (LNKS, nonaketide part of lovastatin [46]); MlcA (nonaketide part of citrinin; [47]), EQS (equisetin; [48]) and FusS (fusarin; [49]). DHPKS1 has also a relatively high homology (Table 1) with the Magnaporthe grisea gene ACE1 encoding a putative PKS expressed exclusively during penetration of $M$. grisea into leaves and involved in the recognition of the fungus by resistant rice varieties carrying the resistance gene Pi33, thus revealing a role for avirulence $[50,51]$. Orthologous to DhPKS1 is also AbPKS9 (DEP5) gene involved in biosynthesis of depudecin, an 11 linear polyketide inhibitor of histone deacetylase (HDAC) virulence factor of the fungus $A$. brassicicola [52].

Among the functionally characterized PKSs DhPKS1 orthologs, there is also $\operatorname{lov} B$ of $A$. terreus, which synthesizes the nonaketide chain of lovastatin, a 3hydroxy-3-methylglutaryl coenzyme A (HMG-CoA) reductase inhibitor [53]. A. terreus has been known to carry an unusual $P K S$ gene cluster for the polyketides in which two PKS genes (lovB and $\operatorname{lov} F$ ) are closely linked in the cluster and are required for the biosynthesis of the nonaketide and the diketide moieties of the compound, respectively [54]. Interestingly, we also found that LovF of A. terreus was homologous to DhPKS24, suggesting the presence in D. helianthi 7/96 of a similar $P K S$ gene cluster. The same hypothesis has been formulated for the biosynthesis of both zearalenone in Gibberella zeae [55] and the linear polyketide T-toxin in race $\mathrm{T}$ of $C$. heterostrophus. The synthesis of T-toxin, essential for fungal virulence on male sterile cytoplasm corn [3], seems to involve a PKS1 together with PKS2 [1].

In our work, as a case study, knock-out mutants of DhPKS1 were produced by targeted DNA integration through Agrobacterium-mediated transformation. This method has been successfully applied to study gene functions in other phytopathogenic and toxigenic fungi $[2,56]$. The presence of a single copy of the T-DNA made the analysis of the transformants straightforward. Unfortunately, it was not possible to confirm the above results by performing experiments with complementation mutants. The reason why no double mutants were obtained is unknown, but it seems that this fungal strain cannot be doubly transformed. As a result of DhPKS1 gene inactivation, reduced fungal virulence on a susceptible sunflower cultivar was observed. Indeed, in contrast with the wild type, mutants caused less visible symptoms after artificial inoculation of fungal mycelia on stem and leaves. This indicates that DhPKS1 could be involved in virulence of the sunflower stem canker agent. The DhPKS1 gene disruption also seems to affect in vitro production of toxic secondary metabolites by $D$. helianthi. Liquid filtrates of $\triangle D h P K S 1$ mutants showed a

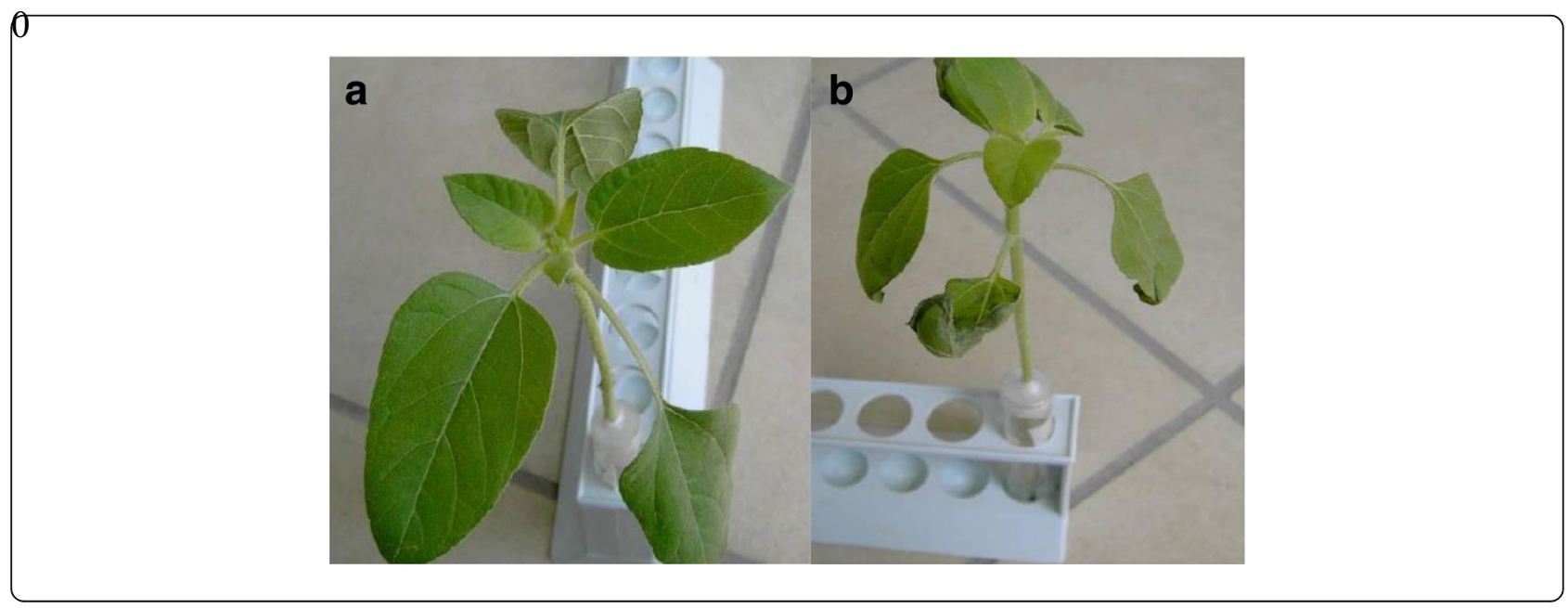




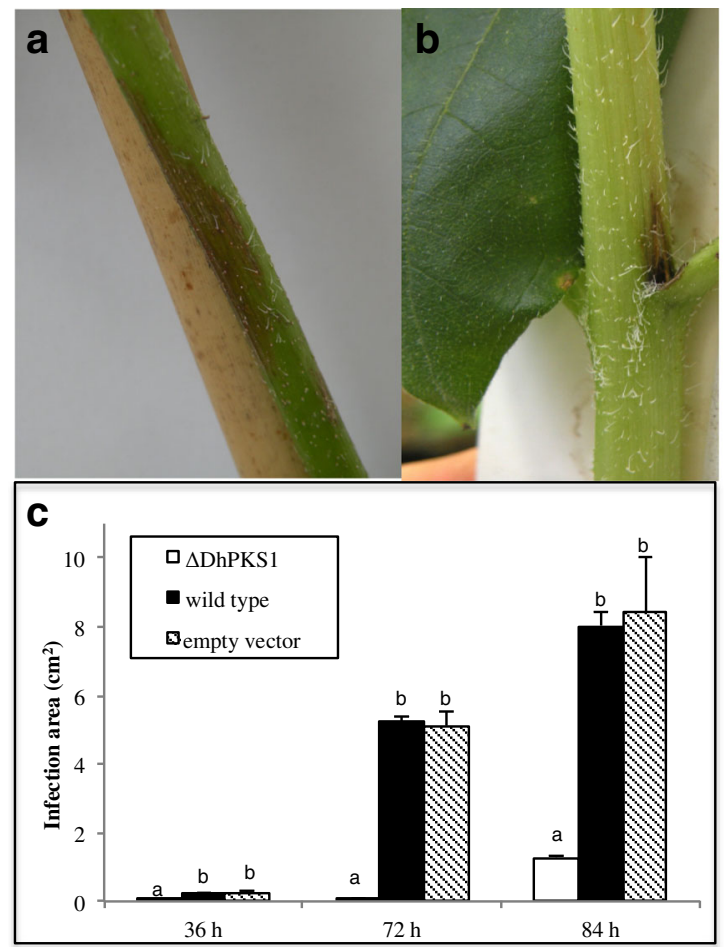

Fig. 7 Pathogenicity bioassay of Diaporthe helianthi strain 7/96 (a) and $\triangle$ DhPKS1 mutant 7/96-Tr1 (b) on sunflower stem. $\mathbf{c}$ Development of necrotic area $\left(\mathrm{cm}^{2}\right)$ on leaf blade in sunflower plants inoculated with the mutant ( $\triangle \mathrm{DhPKS1}$ ), parental (wild type) and empty vector transformant strains. Observations made at 36, 72 and $84 \mathrm{~h}$ after inoculum. Different letters indicate statistically significant differences $(p<0.01)$ at T3 Dunnett test

reduced phytotoxicity on sunflower seedlings. The highly reducing synthase DhPKS1 probably produces a metabolite, not yet identified, which could be involved in the D. helianthi 7/96 strain virulence on sunflower. However, for a better understanding of the possible role of DhPKS1, more studies should be carried out considering also the role of the other PKSs genes that cluster with it.

In previous work [26] the polyketidic metabolite phomozin, an ester of orsellinic acid, was isolated both from culture filtrates of $D$. helianthi and from infected plants, and its possible role in development of symptoms was suggested. Orsellinic acid synthase is the simplest tetraketide synthase and is grouped with the nonreducing PKSs (NR-PKSs). Our results indicate that, in the case of D. helianthi $7 / 96$ orsellinc acid synthase could be coded by DhPKS7 due to its high homology with the $A$. nidulans gene EAA59563 coding for orsellinc acid synthase in A. nidulans [57]. The toxinic theory is supported by the evidence that other phytopathogenic species related to the genus Phomopsis produce toxic metabolites involved in pathogenesis [58-60]. For a disease caused by a Phomopsis species affecting soybean, similar to stem canker of sunflower, the possible involvement of a phytotoxin was also implied [61]. Polyketide synthases have been reported as important virulence factors in other several phytopathogenic fungi such as $C$. heterostrophus [3], Colletotrichum lageniarum [62] and $A$. alternata [63]. In C. nicotianae, the genes CTB1 and CTB3 encode two polyketide synthases, involved in the biosynthesis of cercosporin, a photoactivated perylenequinone toxin, which play a key role in fungal pathogenesis $[64,65]$.

\section{Conclusions}

The PKS sequences reported here are a new important resource that will be useful for further research in the biology, ecology and evolution of D. helianthi and in general of fungal plant pathogens. Further investigation is necessary to fully understand the role of $D$. helianthi PKS genes. Moreover, it will be very important to verify if the PKSs identified in D. helianthi sensu stricto are also present in other species of Diaporthe, which have been associated with sunflower stem canker.

\section{Additional file}

Additional file 1: List of the 40 putative PKS in Diaporthe helianth isolate 7/96 and related information. Domain analyses revealed that most PKS genes coded by $D$. helianthi are highly reducing PKSs, whereas only eight PKSs lack reducing domains and cluster with non-reducing PKSs. In grey are highlighted the genes partially sequenced. (XLSX $76 \mathrm{~kb}$ )

\section{Abbreviations}

ACP: Acyl carrier protein; AT: Acyltransferase; DH: Dehydratase; EQS: Equisetin; ER: Enoylreductase; HDAC: Histone deacetylase; HMG-CoA: 3-hydroxy-3methylglutaryl coenzyme A; Hph: Hygromycin phosphotransferase; KR: Ketoreductase; KS: Ketosynthase; LNKS: Nonaketide part of lovastatin; Lov: Lovastatin; MeT: Methyltransferase; NRPS: Nonribosomal peptide synthetase; PKSs: Polyketide synthases; PP: Phosphopantetheine;

TE: Thioesterase

\section{Acknowledgements}

The Authors take this opportunity to remember prof. Giovanni Del Sorbo who started this study and to thanks dr. Paolo Alfonso Pedata who helped with statistical analysis.

\section{Funding}

This project was financially supported by the projects: BIP Biolndustrial Processes, CUP: B25C13000290007 and CARINA, CUP: B25B09000080007 and by the PhD program of the University of Palermo.

\section{Availability of data and materials}

The reassembled WGS genome of D. helianthi strain 7/96 is present in NCBI GenBank with accession number: MAVT00000000.2.

The datasets used and analysed during the current study are available from the corresponding author on reasonable request.

\section{Authors' contributions}

$M R$ and FS designed the main aims of this work and wrote the manuscript. $M R$ and RB performed genomic characterization of putative PKSs genes, RB conducted the different bioinformatic analyses; CP and MR performed gene disruption and virulence assays, DNA isolation and purification, and the different molecular biology techniques used in this study. MR, FS, RB, CP, SOC, MMM, GF, MV, GMSL and GV provided guidance in the drafting of the manuscript and contributed to acquisition, analysis and interpretation of data. All authors read, corrected and approved the final manuscript. 


\section{Ethics approval and consent to participate}

Not applicable.

\section{Consent for publication \\ Not applicable}

\section{Competing interests}

The authors declare that they have no competing interests.

\section{Publisher's Note}

Springer Nature remains neutral with regard to jurisdictional claims in published maps and institutional affiliations.

\section{Author details}

'Istituto per la Protezione Sostenibile delle Piante, CNR-IPSP, Via Università 133, 80055 Portici (Naples), Italy. ${ }^{2}$ Université de Brest, EA 3882, Laboratoire Universitaire de Biodiversité et Ecologie Microbienne, IBSAM, ESIAB, Technopôle Brest-Iroise, 29280 Plouzané, France. ${ }^{3}$ Dipartimento di Agricoltura, Alimentazione e Ambiente, Università di Catania, 95123 Catania, Italy. ${ }^{4}$ Consiglio per la ricerca in agricoltura e l'analisi dell'economia agraria, Centro di ricerca Orticoltura e Florovivaismo, sede di Pontecagnano, via Cavalleggeri 25, 84098 Pontecagnano (Salerno), Italy. ${ }^{5}$ Dipartimento di Scienze AgroAlimentari, Ambientali e Animali, Università di Udine, via Scienze, Udine, Italy. ${ }^{6}$ Scuola Normale Superiore di Pisa, 56126 Pisa, Italy. ${ }^{7}$ Dipartimento di Scienze Agrarie, Alimentari e Agro-Ambientali, Università di Pisa, 56124 Pisa, Italy. ${ }^{8}$ Dipartimento di Gestione dei Sistemi Agrari e Forestali, Università Mediterranea di Reggio Calabria, 89061 Reggio Calabria, Italy. ${ }^{9}$ Dipartimento di Agraria, Università di Napoli Federico II, 80055 Portici (Naples), Italy.

\section{Received: 7 June 2017 Accepted: 20 December 2017}

\section{Published online: 06 January 2018}

\section{References}

1. Baker SE, Kroken S, Inderbitzin P, Asvarak T, Li BY, Shi L, Yoder OC, Turgeon BG. Two polyketide synthase-encoding genes are required for biosynthesis of the polyketide virulence factor, T-toxin, by Cochliobolus heterostrophus. Mol Plant-Microbe Interact. 2006;19(2):139-49.

2. Zhang A, Lu P, Dahl-Roshak AM, Paress PS, Kennedy S, Tkacz JS, An Z. Efficient disruption of a polyketide synthase gene (pks1) required for melanin synthesis through Agrobacterium-mediated transformation of Glarea lozoyeasis. Mol Gen Genomics. 2003;268(5):645-55.

3. Yang G, Rose MS, Turgeon BG, Yoder OC. A polyketide synthase is required for fungal virulence and production of the polyketide T-toxin. Plant Cell. 1996:8(11):2139-50.

4. Khosla C, Gokhale RS, Jacobsen JR, Cane DE. Tolerance and specificity of polyketide synthases. Annu Rev Biochem. 1999;68:219-53.

5. Shen B. Polyketide biosynthesis beyond the type I, II and III polyketide synthase paradigms. Curr Opin Chem Biol. 2003;7(2):285-95.

6. Crawford JM, Townsend CA. New insights into the formation of fungal aromatic polyketides. Nat Rev Microbiol. 2010;8(12):879-89.

7. Simpson TJ. Fungal polyketide biosynthesis - a personal perspective. Nat Prod Rep. 2014;31(10):1247-52.

8. Vederas JC. Explorations of fungal biosynthesis of reduced polyketides - a personal viewpoint. Nat Prod Rep. 2014;31(10):1253-9.

9. Fujii I. Functional analysis of fungal polyketide biosynthesis genes. J Antibiot (Tokyo). 2010;63(5):207-18.

10. Fujii I, Watanabe A, Ebizuka Y. More functions for multifunctional Polyketide Synthases. In: Tkacz JS, Lange L, editors. Advances in fungal biotechnology for industry, agriculture, and medicine. Boston: Springer US; 2004. p. 97-125.

11. Muntanola-Cvetkovic M, Vukojevic J, Mihaljcevic M. The systemic nature of the sunfluower disease caused by Diaporthe helianthi. Can J Bot. 1991;69(7):1552-6.

12. Acimovic M, Straser N. Phomopsis sp. - novi parazit suncokreta. (Phomopsis sp. a new sunflower parasite). Zastita Bilja. 1982;33(2)

13. Herr $\amalg$, Lipps PE, Watters BL. Diaporthe stem canker of sunflower. Plant Dis. 1983;67:911-3.

14. Delos M, Moinard J. Évolution du Phomopsis du tournesol en France: un bref historique. Phytoma. 1995;473:22-4.

15. Gulya T, Rashid KY, Masirevic SM. Sunflower diseases. In: AAE S, editor. Sunflower technology and production. Madison: ASA-CSSA-SSSA; 1997. p. 263-379.
16. Diaz Franco A, Ortegon Morales A. Influence of sunflower stem canker (Diaporthe helianthi) on seed quality and yield during seed development. Agronomie. 2003;23(7):581-92. https://doi.org/10.1051/agro:2003032.

17. Zazzerini A, Tosi L, Losavio N. Rilievi fitopatoligici su varietà di girasole a confronto nel 1987. L'informatore Agrario. 1988;13:85-88.

18. Zazzerini A, Tosi L. Situazione delle fitopatie del girasole in Italia (1970-88). Informatore Fitopatologico. 1990;2:25-8.

19. Battilani P, Rossi V, Girometta B, Delos M, Rouzet J, André N, Esposito S. Estimating the potential development of Diaporthe helianthi epidemics in Italy. EPPO Bull. 2003;33:427-31.

20. Pecchia S, Mercatelli E, Vannacci G. Intraspecific diversity within Diaporthe helianthi: evidence from rDNA intergenic spacer (IGS) sequence analysis. Mycopathologia. 2004;157(3):317-26.

21. Rekab D, Del Sorbo G, Reggio C, Zoina A, Firrao G. Polymorphisms in nuclear rDNA and mtDNA reveal the polyphyletic nature of isolates of Phomopsis pathogenic to sunflower and a tight monophyletic clade of defined geographic origin. Mycol Res. 2004;108:393-402.

22. Vergara M, Capasso T, Gobbi E, Vannacci G. Plasmid distribution in European Diaporthe helianthi isolates. Mycopathologia. 2005;159(4):591-9.

23. Thompson SM, Tan YP, Young AJ, Neate SM, Aitken EAB, Shivas RG. Stem cankers on sunflower (Helianthus annuus) in Australia reveal a complex of pathogenic Diaporthe (Phomopsis) species. Persoonia. 2011;27:80-9.

24. Mathew FM, Alananbeh KM, Jordahl JG, Meyer SM, Castlebury LA, Gulya TJ, Markell SG. Phomopsis stem canker: a reemerging threat to sunflower (Helianthus annuus) in the United States. Phytopathology. 2015;105(7):990-7.

25. Vergara M, Cristani C, Regis C, Vannacci G. A coding region in Diaporthe helianthi reveals genetic variability among isolates of different geographic origin. Mycopathologia. 2004;158(1):123-30.

26. Mazars C, Rossignol M, Auriol P, Klaebe A. Phomozin, a phytotoxin from Phomopsis helianthi, the causal agent of stem canker of sunflower. Phytochemistry. 1990;29(11):3441-4.

27. Mazars C, Canivenc E, Rossignol M, Auriol P. Production of phomozin in sunflower following artificial inoculation with Phomopsis helianthi. Plant Sci. 1991;75(2):155-60.

28. Avantaggiato $G$, Solfrizzo M, Tosi L, Zazzerini A, Fanizzi FP, Visconti A. Isolation and characterization of phytotoxic compounds produced by Phomopsis helianthi. Nat Toxins. 1999;7(3):119-27.

29. Baroncelli R, Scala F, Vergara M, Thon MR, Ruocco M. Draft whole-genome sequence of the Diaporthe helianthi 7/96 strain, causal agent of sunflower stem canker. Genomics Data. 2016;10:151-2.

30. Urban M, Cuzick A, Rutherford K, Irvine A, Pedro H, Pant R, Sadanadan V, Khamari L, Billal S, Mohanty S, et al. PHI-base: a new interface and further additions for the multi-species pathogen-host interactions database. Nucleic Acids Res. 2017;45:D604-10.

31. Bankevich A, Nurk S, Antipov D, Gurevich AA, Dvorkin M, Kulikov AS, Lesin VM, Nikolenko SI, Pham S, Prjibelski AD, et al. SPAdes: a new genome assembly algorithm and its applications to single-cell sequencing. J Comput Biol. 2012;19(5):455-77.

32. Simao FA, Waterhouse RM, loannidis P, Kriventseva EV, Zdobnov EM. BUSCO: assessing genome assembly and annotation completeness with single-copy orthologs. Bioinformatics. 2015;31(19):3210-2.

33. Holt C, Yandell M. MAKER2: an annotation pipeline and genome-database management tool for second-generation genome projects. BMC Bioinformatics. 2011;12:491.

34. Karlsson M, Durling MB, Choi J, Kosawang C, Lackner G, Tzelepis GD, Nygren K, Dubey MK, Kamou N, Levasseur A, et al. Insights on the evolution of mycoparasitism from the genome of Clonostachys rosea. Genome Biol Evol. 2015;7(2):465-80.

35. Goujon M, McWilliam H, Li WZ, Valentin F, Squizzato S, Paern J, Lopez R. A new bioinformatics analysis tools framework at EMBL-EBI. Nucleic Acids Res. 2010;38:W695-9.

36. Katoh K, Rozewicki J, Yamada KD. MAFFT online service: multiple sequence alignment, interactive sequence choice and visualization. Brief Bioinform. 2017;1-7. https://doi.org/10.1093/bib/bbx108.

37. Raeder $U$, Broda P. Rapid preparation of DNA from filamentous fungi. Lett Appl Microbiol. 1985;1:17-20.

38. Pane C, Rekab D, Firrao G, Ruocco M, Scala F. A novel gene coding for an $A B C$ transporter in Botrytis cinerea (Botryotinia fuckeliana) is involved in resistance to H2O2. Journal of Plant Pathology. 2008;90:(3):453-462.

39. de Groot MJ, Bundock P, Hooykaas PJ, Beijersbergen AG. Agrobacterium tumefaciens-mediated transformation of filamentous fungi. Nat Biotechnol. 1998;16(9):839-42 
40. Mozo T, Hooykaas PJJ. Electroporation of megaplasmids into Agrobacterium. Plant Mol Biol. 1991;16(5):917-8.

41. Kroken S, Glass NL, Taylor JW, Yoder OC, Turgeon BG. Phylogenomic analysis of type I polyketide synthase genes in pathogenic and saprobic ascomycetes. Proc Natl Acad Sci U S A. 2003;100(26):15670-5.

42. Galagan JE, Calvo SE, Borkovich KA, Selker EU, Read ND, Jaffe D, FitzHugh W, Ma LJ, Smirnov S, Purcell S, et al. The genome sequence of the filamentous fungus Neurospora crassa. Nature. 2003;422(6934):859-68.

43. Kennedy J, Auclair K, Kendrew SG, Park C, Vederas JC, Hutchinson CR. Modulation of polyketide synthase activity by accessory proteins during lovastatin biosynthesis. Science. 1999;284(5418):1368-72.

44. Dalmais B, Schumacher J, Moraga J, LEP P, Tudzynski B, Collado IG, Viaud M. The Botrytis cinerea phytotoxin botcinic acid requires two polyketide synthases for production and has a redundant role in virulence with botrydial. Mol Plant Pathol. 2011;12(6):564-79.

45. Schumacher J, Viaud M, Simon A, Tudzynski B. The Ga subunit BCG1, the phospholipase $\mathrm{C}$ (BCPLC1) and the calcineurin phosphatise co-ordinately regulate gene expression in the grey mould fungus Botrytis cinerea. Mol Microbiol. 2008;67:1027-50.

46. Sutherland A, Auclair K, Vederas JC. Recent advances in the biosynthetic studies of lovastatin. Curr Opin Drug Discov Dev. 2001;4(2):229-36.

47. Abe Y, Suzuki T, Ono C, Iwamoto K, Hosobuchi M, Yoshikawa H. Molecular cloning and characterization of an ML-236B (compactin) biosynthetic gene cluster in Penicillium citrinum. Mol Gen Genomics. 2002;267(5):636-46.

48. Sims JW, Fillmore JP, Warner DD, Schmidt EW. Equisetin biosynthesis in Fusarium heterosporum. Chem Commun (Camb). 2005;2:186-8.

49. Song Z, Cox RJ, Lazarus CM, Simpson TT. Fusarin C biosynthesis in Fusarium moniliforme and Fusarium venenatum. Chembiochem. 2004;5(9):1196-203.

50. Bohnert HU, Fudal I, Dioh W, Tharreau D, Notteghem JL, Lebrun MH. A putative polyketide synthase/peptide synthetase from Magnaporthe grisea signals pathogen attack to resistant rice. Plant Cell. 2004;16(9):2499-513.

51. Fudal I, Collemare J, Bohnert HU, Melayah D, Lebrun MH. Expression of Magnaporthe grisea avirulence gene ACE1 is connected to the initiation of appressorium-mediated penetration. Eukaryot Cell. 2007;6(3):546-54.

52. Wight WD, Kim KH, Lawrence CB, Walton JD. Biosynthesis and role in virulence of the histone deacetylase inhibitor depudecin from Alternaria brassicicola. Mol Plant-Microbe Interact. 2009;22(10):1258-67.

53. Hendrickson L, Davis CR, Roach C, Nguyen DK, Aldrich T, McAda PC, Reeves CD. Lovastatin biosynthesis in Aspergillus terreus: characterization of blocked mutants, enzyme activities and a multifunctional polyketide synthase gene. Chem Biol. 1999;6(7):429-39.

54. Ma SM, Tang Y. Biochemical characterization of the minimal polyketide synthase domains in the lovastatin nonaketide synthase LovB. FEBS J. 2007; 274(11):2854-64.

55. Kim YT, Lee YR, Jin J, Han KH, Kim H, Kim JC, Lee T, Yun SH, Lee YW. Two different polyketide synthase genes are required for synthesis of zearalenone in Gibberella zeae. Mol Microbiol. 2005;58(4):1102-13.

56. Schumann J, Hertweck C. Advances in cloning, functional analysis and heterologous expression of fungal polyketide synthase genes. J Biotechnol. 2006;124(4):690-703

57. Schroeckh V, Scherlach K, Nutzmann HW, Shelest E, Schmidt-Heck W, Schuemann J, Martin K, Hertweck C, Brakhage AA. Intimate bacterial-fungal interaction triggers biosynthesis of archetypal polyketides in Aspergillus nidulans. Proc Natl Acad Sci U S A. 2009;106(34):14558-63.

58. Evidente A, Rodeva R, Andolfi A, Stoyanova Z, Perrone C, Motta A. Phytotoxic polyketides produced by Phomopsis foeniculi, a strain isolated from diseased Bulgarian fennel. Eur J Plant Pathol. 2011;130(2):173-82.

59. Patwardhan SA, Pandey RC, Dev S, Pendse GS. Toxic cytochalasins of Phomopsis paspalli, a pathogen of kodo millet. Phytochemistry. 1974;13: 1985-8.

60. Wheeler MM, Wheeler DMS, Peterson GW. Anthraquinone pigments from the phytopathogen Phomopsis juniperovora hahn. Phytochemistry. 1974;14: 288-9.

61. Lalitha B, Snow JP, Berggren GT. Phytotoxin production by Diaporthe phaseolorum var. caulivora, the causal organism of stem canker of soybean. Phytopathology. 1989;79:499-504

62. Takano Y, Kubo Y, Shimizu K, Mise K, Okuno T, Furusawa I. Structural analysis of PKS1, a polyketide synthase gene involved in melanin biosynthesis in Colletotrichum lagenarium. Mol Gen Genet. 1995;249(2):162-7.

63. Izumi Y, Ohtani K, Miyamoto Y, Masunaka A, Fukumoto T, Gomi K, Tada Y, Ichimura K, Peever TL, Akimitsu K. A polyketide synthase gene, ACRTS2, is responsible for biosynthesis of host-selective ACR-toxin in the rough lemon pathotype of Alternaria alternata. Mol Plant-Microbe Interact. 2012;25(11):1419-29.

64. Choquer M, Dekkers KL, Chen HQ, Cao L, Ueng PP, Daub ME, Chung KR. The CTB1 gene encoding a fungal polyketide synthase is required for cercosporin biosynthesis and fungal virulence of Cercospora nicotianae. Mol Plant-Microbe Interact. 2005;18(5):468-76.

65. Dekkers KL, You BJ, Gowda VS, Liao HL, Lee MH, Bau HJ, Ueng PP, Chung KR. The Cercospora nicotianae gene encoding dual O-methyltransferase and FAD-dependent monooxygenase domains mediates cercosporin toxin biosynthesis. Fungal Genet Biol. 2007;44(5):444-54.

66. Desjardins AE, Munkvold GP, Plattner RD, Proctor RH. FUM1-a gene required for fumonisin biosynthesis but not for maize ear rot and ear infection by Gibberella moniliformis in field tests. Mol Plant-Microbe Interact. 2002;15(11):1157-64.

67. Zhao X, Wang Y, Zhao $Y$, Huang $Y$, Zhang $K Q$, Yang J. Malate synthase gene AoMls in the nematode-trapping fungus Arthrobotrys oligospora contributes to conidiation, trap formation, and pathogenicity. Appl Microbiol Biotechnol. 2014;98(6):2555-63.

68. Brown DWL, Lee S-H, Kim L-H, Ryu J-G, Lee S, Seo Y, Kim YH, Busman M, Yun S-H, Proctor RH, Lee T. Identification of a 12-gene fusaric acid biosynthetic gene cluster in Fusarium species through comparative and functional genomics. Mol Plant-Microbe Interact. 2015;28(3):319-32.

69. Gaffoor I, Trail F. Characterization of two polyketide synthase genes involved in zearalenone biosynthesis in Gibberella zeae. Appl Environ Microbiol. 2006 72(3):1793-9.

70. Ludwig N, Lohrer M, Hempel M, Mathea S, Schliebner I, Menzel M, Kiesow A, Schaffrath U, Deising HB, Horbach R. Melanin is not required for turgor generation but enhances cell-wall rigidity in appressoria of the corn pathogen Colletotrichum graminicola. Mol Plant-Microbe Interact. 2014; 27(4):315-27.

71. Gaffoor I, Brown DW, Plattner R, Proctor RH, Qi W, Trail F. Functional analysis of the polyketide synthase genes in the filamentous fungus Gibberella zeae (anamorph Fusarium graminearum). Eukaryot Cell. 2005:4(11):1926-33.

72. Garcia-Rodas R, Trevijano-Contador N, Roman E, Janbon G, Moyrand F, Pla J, Casadevall A, Zaragoza O. Role of Cln1 during melanization of Cryptococcus neoformans. Front Microbiol. 2015;6:798.

73. Watanabe A, Fujii I, Tsai H, Chang YC, Kwon-Chung KJ, Ebizuka Y. Aspergillus fumigatus alb1 encodes naphthopyrone synthase when expressed in Aspergillus oryzae. FEMS Microbiol Lett. 2000;192(1):39-44.

74. Langfelder K, Jahn B, Gehringer H, Schmidt A, Wanner G, Brakhage AA. Identification of a polyketide synthase gene (pksP) of Aspergillus fumigatus involved in conidial pigment biosynthesis and virulence. Med Microbiol Immunol. 1998;187(2):79-89.

75. Feng B, Wang X, Hauser M, Kaufmann S, Jentsch S, Haase G, Becker JM, Szaniszlo PJ. Molecular cloning and characterization of WdPKS1, a gene involved in dihydroxynaphthalene melanin biosynthesis and virulence in Wangiella (Exophiala) dermatitidis. Infect Immun. 2001;69(3):1781-94.

76. Leng $Y$, Zhong S. Sfp-type 4'-phosphopantetheinyl transferase is required for lysine synthesis, tolerance to oxidative stress and virulence in the plant pathogenic fungus Cochliobolus sativus. Mol Plant Pathol. 2012;13(4):375-87.

77. Chooi YH, Muria-Gonzalez MJ, Mead OL, Solomon PS. SnPKS19 encodes the Polyketide Synthase for Alternariol Mycotoxin Biosynthesis in the wheat pathogen Parastagonospora nodorum. Appl Environ Microbiol. 2015;81(16): 5309-17.

\section{Submit your next manuscript to BioMed Central and we will help you at every step:}

- We accept pre-submission inquiries

- Our selector tool helps you to find the most relevant journal

- We provide round the clock customer support

- Convenient online submission

- Thorough peer review

- Inclusion in PubMed and all major indexing services

- Maximum visibility for your research

Submit your manuscript at www.biomedcentral.com/submit 